\title{
Qualitative Analysis of Mango (Mangifera indica L.) Fruits at Different Maturity Stages
}

\author{
M. Ittafaqul Azad ${ }^{1}$, M. Golam Mortuza ${ }^{2}, \mathrm{M} . \mathrm{Al}-\mathrm{Amin}^{3}$ \\ M. N. A. Naher ${ }^{4}$ and S.M. Khorshed Alam ${ }^{5^{*}}$ \\ ${ }^{1}$ DAE, Rajshahi $;{ }^{2}$ Regional Agricultural Research Station, Ishwardi, Pabna $;{ }^{3}$ Biotechnology Division, BARI; \\ ${ }^{4}$ LEAF Project, Inter Cooperation, Rajshahi and ${ }^{5}$ BARC, New Airport Road, Farmgate, Dhaka, Bangladesh \\ *Corresponding author and Email: k.alam@barc.gov.bd
}

\begin{abstract}
Some chemical compositions of mango harvested at 24, 18, 12, 6 days before optimum maturity and at optimum maturity were analyzed. The amount of ascorbic acid, $\beta$-carotene and sugars of the harvested mangoes were significantly influenced by the stages of harvest and period of storage. Amount of ascorbic acid of the harvested mango fruits was the highest just after harvest. It was sharply declined with the elapse of time in storage. Fruits harvested before optimum maturity showed the highest amount of ascorbic acid, which decreased in delay of harvest. $\beta$-carotene was quite low at harvest but rapidly increased in storage. Fruits harvested before optimum maturity showed minimum $\beta$-carotene and it rapidly increased in late harvested fruits. Total sugar, reducing sugar and non reducing sugar were sharply increased at optimum ripe stage, while slightly declined at last edible stage. All the sugars were the lowest at earliest harvests, which increased gradually with delay in harvest.
\end{abstract}

Keywords: Qualitative analysis, mango, ascorbic acid, $\beta$-carotene

\section{Introduction}

Mango (Mangifera indica L.) is an important fruit of Bangladesh. It occupied an area of 61885 hectare with an annual production of 662100 metric tones (BBS, 2005). It contains appreciable quantity of vitamins, soluble sugars and minerals which are readily available and easily assumable in human body (Singh, 1990). After harvest, fruits undergo many physiological and biochemical changes during storage. Apart from this change, microbial decay contributes to postharvest losses during ripening and storage. The storage life of a fruit could be significantly prolonged through slowing down of the process leading to ripening and controlling of the microbial decay.

Mango manifests high post harvest losses because of its high perishability and climacteric pattern of respiration. Rubbi et al. (1985) reported 35-38\% postharvest losses of mango in Bangladesh. Physiological maturity is another important factor regulating different physiological and biochemical changes during storage and ripening of mango. Storage quality of mango is highly dependent upon the stage of harvest. Mango harvested at full maturity had reduced shelf life, while early harvest caused more weight loss but showed better storability (Shahjahan et al., 1994). Nutritional and edible qualities of mango are affected by the application of the postharvest treatments and also by harvesting the fruits at various stages of maturity. Several authors studied the physical characteristics (Uddin et al., 2006; Alam et al., 2007) and physico-chemical changes during ripening and storage of mango (De Leon and De Lime, 1968; Krishnamurthy and Subramanium, 1973; Subramanium et al., 1975; Medlicott and Jager, 1987). 
However, there is a lack of established technology regarding harvesting, handling, transportation, storage and ripening of mangoes which often results in high level of wastage, unsynchronized ripening and poor quality fruits. The present study was therefore, undertaken to find out the optimum harvest stage of four commercial mango varieties based on the changes of nutritional qualities of harvested mango fruits.

\section{Materials and Methods}

The experiment was conducted at Chapai Nawabganj during 1998-99 fruiting season. Among the most important mango varieties commercially grown at Chapai Nawabganj, four varieties namely Fazli, Khirsapat, Langra and Gopalbhog were selected for this investigation. Among the selected cultivars Gopalbhog is early, Khirsapat and Langra are mid season, while Fazli is late. Fruits were collected from the Regional Horticulture Research Station farm at Chapai Nawabganj. The fruits were harvested at 5 different maturity stages. The first harvest $\left(\mathrm{S}_{1}\right)$ was done at 24 days before optimum maturity (DBOM), second harvest $\left(\mathrm{S}_{2}\right)$ at $18 \mathrm{DBOM}$, third harvest $\left(\mathrm{S}_{3}\right)$ at $12 \mathrm{DBOM}$, fourth harvest $\left(\mathrm{S}_{4}\right)$ at 6 DBOM, and the final harvest $\left(\mathrm{S}_{5}\right)$ at optimum maturity. The experiment was done in a factorial completely randomized design using three replications. Thirty fruits of uniform size and shape were harvested from each stages of harvest. The optimum stages of harvest was 88 days for Gopalbhog, 92 days for Khirsapat, 105 days for Langra and 120 days for Fazli after fruit set (Shahjahan et al., 1994). Dates of fruit set were noted down for accurate age of the fruits.

Thirty fruits of uniform size and shape were harvested from each stages of harvest. Harvested fruits were kept in the laboratory $\left(28-37^{0} \mathrm{C}\right)$ for ripening. Ascorbic acid, $\beta$-carotine, total sugars, reducing sugars and non-reducing sugars of the mango samples were examined at 3 stages of storage, once just after harvest, once at full ripe and finally at the end of storage period. Chemical composition of the samples was determined at the Biochemistry laboratory of Rajshahi
University. Ascorbic acid content of the flesh was estimated by Bessey's titrimetric method (Bessey and King, 1933). $\beta$-carotene was determined using methods of Biochemical analysis (Anonymous, 1967). Total sugar content of flesh was estimated by Anthrone method (Jayarman, 1981). The amount of total sugar was calculated from the standard curve of glucose. The percentage of total sugar present in the mango pulp was determined as:

Percent of total sugar (g/100g pulp)

$$
=\frac{\text { Amount of sugar obtained }}{\text { Weight of mango pulp }} \times 100
$$

Reducing sugar content was measured following the DNS method (Miller, 1972). Non reducing sugar content was determined by subtracting the reducing sugar content from total sugar content (Banik, 1995). Non-reducing sugar content was determined by using the following formula.

Percent of non-reducing sugar $=(\%$ Total sugar $\%$ Reducing sugar) X 0.95

Data were analyzed using analysis of variance (ANOVA) for a completely randomized design and treatment means were compared by DMRT.

\section{Results and Discussion}

\subsection{Ascorbic acid}

Ascorbic acid content of the harvested mango fruits was significantly influenced by the stages of harvest and period of storage (Table 1). It was the highest just after harvest and gradually declined with the passage of time, while it was the lowest at last edible stage. Early harvested fruits showed higher amount of ascorbic acid as compared to the last harvest with the highest amount being recorded at $S_{1}$ and the lowest at $S_{5}$ harvest stage. The results of the present study agree with that of Shyamalamma et al. (1995). Mango varieties showed significant differences in ascorbic acid content. At initial stage, Langra contained the highest amount of ascorbic acid, which sharply decreased at full ripe stage. Fazli and Khirsapat had moderate amounts, while it was the minimum in Gopalbhog. At full ripe and 
last edible stage, ascorbic acid content was the highest in Fazli and the lowest in Gopalbhog. The results indicated that ascorbic acid content gradually declined in all varieties as they advanced towards the last edible stage.

\section{2. $\beta$-carotene}

Stages of harvest and storage period had significant effect on $\beta$-carotene content of mango fruits. The amount of $\beta$-carotene was increased with the progress of storage (Table 1). It was the minimum after harvest and was maximum at last edible stage. Minimum $\beta$-carotene was recorded in the fruits harvested first. The amount of $\beta$ carotene increased gradually with the delay in harvest and being highest at last harvest. Similar trend was noted in all periods of storage. The findings of the study conformed to those of Absar et al. (1993) and Mondal et al. (1995). Significant variations in $\beta$-carotene content were observed among the mango varieties. It was the highest in Langra and the lowest in Gopalbhog both after harvest and full ripe stage. At last edible stage, the highest amount of $\beta$-carotene was noted in Khirsapat and the lowest in Gopalbhog. It progressively increased with the period of storage in all the varieties. Similar results were reported by Bhatnagor and Subramanyam (1973).

\subsection{Total sugar}

Total sugar content in mango fruits was significantly influenced by stages of harvest and storage (Table 2). It rapidly increased from harvest to ripe stage and then slightly decreased at the last edible stage. It was the minimum in fruits harvested first, gradually increased with the delay in harvest and was the maximum in last harvest $\left(\mathrm{S}_{5}\right)$. Similar results have been reported by Shyamalamma et al. (1995) in ripe 'Mallika' mangoes. The mango varieties exhibited significant differences in total sugar content at all stages of storage. The highest total sugar content was recorded in Gopalbhog and the lowest in Fazli at ripe stage. The results revealed that total sugar sharply reached the maximum level at full ripe stage and then fall down slightly at the last edible stage in all the varieties.

Table 1. Effect of stage of harvest on ascorbic acid and $\beta$-carotene content of mango fruits.

\begin{tabular}{l|c|c|c|c|c|c}
\hline \multirow{2}{*}{$\begin{array}{c}\text { Treatment } \\
\text { Stages/var. }\end{array}$} & \multicolumn{2}{|c}{ Ascorbic acid $(\mathrm{mg} / 100 \mathrm{~g})$ at } & \multicolumn{3}{c}{$\beta$-carotene $(\mu \mathrm{g} / 100 \mathrm{~g})$ at } \\
\cline { 2 - 7 } & Harvest & Ripening & $\begin{array}{c}\text { Last edible } \\
\text { stage }\end{array}$ & Harvest & Ripening & $\begin{array}{c}\text { Last edible } \\
\text { stage }\end{array}$ \\
\hline 24 DBOM & $37.33 \mathrm{a}$ & $17.14 \mathrm{a}$ & $12.50 \mathrm{a}$ & $320 \mathrm{e}$ & $1121 \mathrm{e}$ & $2512 \mathrm{e}$ \\
$18 \mathrm{DBOM}$ & $36.63 \mathrm{~b}$ & $16.80 \mathrm{~b}$ & $12.55 \mathrm{a}$ & $650 \mathrm{~d}$ & $1934 \mathrm{~d}$ & $3635 \mathrm{~d}$ \\
$12 \mathrm{DBOM}$ & $35.83 \mathrm{c}$ & $15.96 \mathrm{c}$ & $12.21 \mathrm{a}$ & $1079 \mathrm{c}$ & $2776 \mathrm{c}$ & $4609 \mathrm{c}$ \\
6 DBOM & $32.99 \mathrm{~d}$ & $15.55 \mathrm{~d}$ & $11.98 \mathrm{a}$ & $1453 \mathrm{~b}$ & $3856 \mathrm{~b}$ & $6372 \mathrm{~b}$ \\
OM & $31.34 \mathrm{e}$ & $15.16 \mathrm{e}$ & $12.59 \mathrm{a}$ & $2123 \mathrm{a}$ & $5049 \mathrm{a}$ & $7521 \mathrm{a}$ \\
Variety & & & & & & \\
Gopalbhog & $26.11 \mathrm{~d}$ & $10.68 \mathrm{~d}$ & $9.50 \mathrm{~d}$ & $735 \mathrm{~d}$ & $2056 \mathrm{~d}$ & $3497 \mathrm{~d}$ \\
Khirsapat & $32.37 \mathrm{c}$ & $13.38 \mathrm{c}$ & $11.33 \mathrm{c}$ & $1235 \mathrm{~b}$ & $2999 \mathrm{~b}$ & $5526 \mathrm{a}$ \\
Langra & $46.32 \mathrm{a}$ & $19.36 \mathrm{~b}$ & $13.27 \mathrm{~b}$ & $13.53 \mathrm{a}$ & $3956 \mathrm{a}$ & $5227 \mathrm{c}$ \\
Fazli & $34.15 \mathrm{~b}$ & $21.34 \mathrm{a}$ & $15.37 \mathrm{a}$ & $1176 \mathrm{c}$ & $2779 \mathrm{c}$ & $5469 \mathrm{~b}$ \\
CV\% & 1.21 & 0.75 & 9.73 & 0.43 & 0.17 & 0.17 \\
\hline
\end{tabular}

Values followed by the same letter(s) in a column are not significantly different $(\mathrm{P} \leq 0.05)$ according to DMRT. $\mathrm{DBOM}=$ Days before optimum maturity, $\mathrm{OM}=$ Optimum maturity. 
Table 2. Effect of stage of harvest on total, reducing and non-reducing sugars of four mango varieties.

\begin{tabular}{|c|c|c|c|c|c|c|c|c|c|}
\hline \multirow{2}{*}{$\begin{array}{l}\text { Treatment } \\
\text { Stage/var. }\end{array}$} & \multicolumn{3}{|c|}{ Total Sugar (\%) at } & \multicolumn{3}{|c|}{ Reducing sugar (\%) at } & \multicolumn{3}{|c|}{$\begin{array}{c}\text { Non-reducing sugar }(\%) \\
\text { at }\end{array}$} \\
\hline & Harvest & Ripening & $\begin{array}{l}\text { Last } \\
\text { edible } \\
\text { stage }\end{array}$ & Harvest & Ripening & $\begin{array}{l}\text { Last } \\
\text { edible } \\
\text { stage }\end{array}$ & Harvest & Ripening & $\begin{array}{c}\text { Last } \\
\text { edible } \\
\text { stage }\end{array}$ \\
\hline $24 \mathrm{DBOM}$ & $2.46 \mathrm{e}$ & $5.20 \mathrm{e}$ & $4.99 \mathrm{e}$ & $1.41 \mathrm{e}$ & $1.81 \mathrm{e}$ & $1.71 \mathrm{e}$ & $1.00 \mathrm{e}$ & $3.22 \mathrm{e}$ & $3.12 \mathrm{e}$ \\
\hline 18 DBOM & $2.93 d$ & $5.44 \mathrm{~d}$ & $5.35 \mathrm{~d}$ & $1.68 \mathrm{~d}$ & $1.88 \mathrm{~d}$ & $1.85 \mathrm{~d}$ & $1.19 \mathrm{~d}$ & $3.39 \mathrm{~d}$ & $3.33 \mathrm{~d}$ \\
\hline $12 \mathrm{DBOM}$ & $3.36 \mathrm{c}$ & $5.81 \mathrm{c}$ & $5.66 \mathrm{c}$ & $1.79 \mathrm{c}$ & $2.00 \mathrm{c}$ & $1.98 \mathrm{c}$ & $1.50 \mathrm{c}$ & $3.62 \mathrm{c}$ & $3.50 \mathrm{c}$ \\
\hline 6 DBOM & $4.11 b$ & $6.10 \mathrm{~b}$ & $6.05 b$ & $1.88 \mathrm{~b}$ & $2.12 \mathrm{~b}$ & $2.09 \mathrm{~b}$ & $2.12 b$ & $3.79 b$ & $3.77 b$ \\
\hline $\mathrm{OM}$ & $4.42 \mathrm{a}$ & $6.39 a$ & $6.27 \mathrm{a}$ & $1.95 \mathrm{a}$ & $2.25 \mathrm{a}$ & $2.21 \mathrm{a}$ & $2.35 \mathrm{a}$ & $3.94 \mathrm{a}$ & $3.86 \mathrm{a}$ \\
\hline \multicolumn{10}{|l|}{ Variety } \\
\hline Gopalbhog & $3.67 \mathrm{a}$ & $6.12 \mathrm{a}$ & $5.95 \mathrm{a}$ & $1.86 \mathrm{a}$ & $2.29 \mathrm{a}$ & $2.13 \mathrm{a}$ & $1.72 \mathrm{a}$ & $3.64 \mathrm{a}$ & $3.63 a$ \\
\hline Khirsapat & $3.52 \mathrm{~b}$ & $5.82 b$ & $5.68 \mathrm{c}$ & $1.76 \mathrm{~b}$ & $1.98 \mathrm{~b}$ & $1.98 \mathrm{~b}$ & $1.68 \mathrm{a}$ & $3.65 \mathrm{a}$ & $3.52 b$ \\
\hline Langra & $3.34 \mathrm{c}$ & $5.79 b$ & $5.75 b$ & $1.70 \mathrm{c}$ & $1.99 \mathrm{~b}$ & $1.93 \mathrm{c}$ & $1.56 \mathrm{~b}$ & $3.61 \mathrm{a}$ & $3.63 \mathrm{a}$ \\
\hline Fazli & $3.31 \mathrm{c}$ & $5.43 \mathrm{c}$ & $5.33 d$ & $1.65 \mathrm{~d}$ & $1.79 \mathrm{c}$ & $1.88 \mathrm{~d}$ & $1.58 \mathrm{~b}$ & $3.46 \mathrm{~b}$ & $3.28 \mathrm{c}$ \\
\hline $\mathrm{CV} \%$ & 3.89 & 2.09 & 1.56 & 1.42 & 1.50 & 2.17 & 4.55 & 2.45 & 2.78 \\
\hline
\end{tabular}

Values followed by the same letter(s) in a column are not significantly different $(\mathrm{P} \leq 0.05)$ according to DMRT. $\mathrm{DBOM}=$ Days before optimum maturity; $\mathrm{OM}=$ Optimum maturity.

\subsection{Non-reducing sugar}

Non-reducing sugars (NRS) in mango fruits was influenced by stages of harvest and storage. It increased at ripe stage but slightly reduced at last edible stage. It became the lowest in early harvested fruits and was the highest in the late harvested fruits (Table 2). The gradual increase of NRS towards advancement of maturity conformed to the findings of Shyamalamma et al. (1995). Among the mango varieties, Gopalbhog and Langra exhibited the highest and lowest NRS, respectively. At full ripe stage, it was the highest and lowest in Khirsapat and Fazli, respectively. The results revealed that NRS rapidly increased from harvest stage and reached the maximum at full ripe stage and then slightly decreased at last edible stage in all varieties. Similar results have been reported by Ali and Mazhar (1960).

\section{Conclusions}

The study revealed that fruits harvested before optimum maturity showed the highest amount of ascorbic acid which decreased in delay of harvest. $\beta$-carotene was quite low at harvest but rapidly increased in storage. The sugar content was the lowest at earliest harvests which increased gradually in late harvested fruits.

\section{References}

Alam, M. A., Mortuza M. G., M. Z. Uddin, Islam M. S. and Barman J. C. 2007. fruit characteristics and fruiting behaviour of some promising mango lines. Journal of Bangladesh Society of Agricultural Science and Technology, 4 (1 \& 2): 101-104.

Ali, N and Mazhar H. 1960. The tree, flower and fruit characteristics of mango. Punjab Fruit Jouranl, 23:81-86.

Absar, N., Karim M. R. and Al-Amin M. 1993. A comparative study on the changes in the physico-chemical composition of ten varieties of mango in Bangladesh at different stages of maturity. Bangladesh Journal of Agricultural Research, 18(2):201-208. 
Anonymous. 1967. The Association of vitamin Chemists. Methods of vitamin assay. InterSci. Pub. London, (3rd ed.), p.98.

Banik, A.K. 1995. Studies on pre and postharvest treatments on shelf life of mango with special reference to major diseases. Ph.D. Thesis, BCKV, West Bengal, p. 52.

BBS. 2005. Statistical Yearbook of Bangladesh. Bangladesh Bureau of Statistics, Planning Division, Ministry of Planning, Dhaka, Bangladesh. p. 156.

Bessey, A.O and King C.G. 1933. The distribution of vitamin $-\mathrm{C}$ in plant and animal tissues and its determination. Journal of Biological Chemistry, 103: 687-693.

Bhatnagar, H.C. and Subramanyam H. 1973. Some aspects of preservation, processing and export of mango and its products. Indian Food Pack, 21(4):33-52.

De Leon, S.Y. and De Lime L.S. 1968. Postharvest changes in some physical and chemical properties of Pico mangoes (Mangifera indica L.). Philippines Journal of Science, 77:337-347.

Jayarman J. 1981. Laboratory manual in Biochemistry. Wiley Eastern Ltd. New Delhi, India, p.53.

Krishnamurthy, H.S. and Subramanyum H. 1973. Pre and posthavest physiology of mango, a review. Tropical Science, 15:1167-1195.

Medlicott, A.P. and Jager M. J. 1987. The development and application of postharvest treatments to manipulate ripening in mangoes. In: Mangoes- a review. (Eds.) Prinsly, T.R. and G.A. Tucker, Commonwealth Sci. Coun., pp.56-77.

Miller, G.L. 1972. Use of di nitro Salicylic acid reagent for determination of reducing sugar. Analytical Chemistry, 31:426-428.

Mondal, M.F., Hassan M.K. and Haque M.S. 1998. Physico-chemical changes and shelf life of mango as influenced by postharvest treatments. Progressive Agriculture, 9(1\&2):77-82.

Mondal, M.F., Rahim M.A. and Pramanik M.A.J. 1995. Effects of different posthavest treatments on physico-chemical changes and shelf life of mango. Bangladesh Horticulture, 23(1\&2): 1-5.

Rubbi, S.F., Rahim M.A. and Rahman K.Q. 1985. Studies on the processing and preservation of mango. Proc. 4th National Symp. of Bangladesh Society of. Horticultural Science, pp.138-148.

Shahjahan, M.S., Sheel M.A., Zaman M.A. and Sakur M.A. 1994. Optimization of harvesting maturities for major mango cultivars in Bangladesh. Bangladesh Journal of Scientific Research, 12(2):209-215.

Shyamalamma, S., Subbaiah T.K., Mukunda G.K. and Khan M.M. 1995. Effect of maturity at harvest on the postharvest behaviour of 'Mallika' mango. Phala Sanskarana. Division of Hort. University of Agril. Sci. GKVK, Bangalore, Karnataka, India. 11(7):43-47.

Singh, R.N. 1990. Mango. Indian Coun. of Agricultural Research, New Delhi. pp.1-6.

Subramanyam, Krishnamurthy H. S. and Parpia H.A.B. 1975. Physiology and biochemistry of mango fruit. Advanced Food Research, 21:223-305.

Uddin, M. Z., Rahim M. A., Alam M. A., Barman J. C. and Wadud M. A. 2006. A study on the physical characteristics of some mango germplasms grown in Mymensingh condition. International Journal of Sustainable Crop Production, 1 (2): 33-38.

Upadhyay, N.P. and Tripathi B.M. 1985. ostharvest changes during storage and ripening $f$ Gaurjeet mango (Mangifera indica L.) fruits. Progressive Horticulture, 17 (1):25-27. 